\title{
Lactobacillus plantarum as Bio-Control Agent during Egg Incubation of African Catfish (Clarias gariepinus) - Effects on Microbial Loads and Water Quality Parameters
}

\author{
Daniel Olusegun Diyaolu ${ }^{1, *}$ (1)
}

${ }^{1}$ Olusegun Agagu University of Science and Technology, Department of Fisheries and Aquaculture Technology, P.M.B. 353, Okitipupa, Nigeria.

\author{
How to cite \\ Diyaolu, D.O., (2022). Lactobacillus plantarum as Bio-Control Agent during Egg Incubation of African Catfish (Clarias gariepinus) - Effects on \\ Microbial Loads and Water Quality Parameters. Aquaculture Studies, 22(4), AQUAST808. http://doi.org/10.4194/AQUAST808
}

\section{Article History}

Received 28 October 2021

Accepted 24 February 2022

First Online 26 February 2022

\section{Corresponding Author}

Tel.: +2347030988645

E-mail: do.diyaolu@oaustech.edu.ng

\section{Keywords}

Probiotics

Hatchlings

Inoculated

Fungi

\begin{abstract}
This study evaluated the heterotrophic bacteria and fungi loads and water quality parameters when Lactobacillus plantarum was employed as bio-control agent during egg incubation of Clarias gariepinus. The $L$. plantarum cells were inoculated into incubating water in 6-litre bowl at bacterial concentration of $2 \times 10^{3}, 2 \times 10^{6}$ and $2 \times 10^{9}$ cfu L $\mathrm{L}^{-1}$. Bowls with $1 \mathrm{ppt}$ tetracycline solution and with no test bacteria / drug served as positive and negative controls respectively. $3 \mathrm{~g}$ of $C$. gariepinus fertilized eggs were incubated in these bowls under static water condition for 30 hours at room temperature, after which hatchability was determined. The water in each bowl was analyzed before, during and after egg incubation. The results indicated that all L. plantarum treatment groups recorded significantly $(p<0.05)$ reduced Enterobacteriaceae and fungi counts in the incubating water, with the optimum concentration recorded at $2 \times 10^{6} \mathrm{cfu} \mathrm{L}^{-1}$. There were significant reductions $(p<0.05)$ in the dissolved oxygen and $\mathrm{pH}$ of water at 30 hours of incubation when compared with the values obtained at 10 hour of incubation in all experimental groups. The fertilized eggs hatched in all treatment groups except those inoculated with $2 \times 10^{9} \mathrm{cfu} \mathrm{L}^{-1}$ L. plantarum, while hatchlings from positive control (tetracycline solution) groups were observed to be less viable than the probiotic-treatment and negative control (non-probiotic treatment) groups. It can be concluded from this study that addition of $2 \times 10^{6} \mathrm{cfu} \mathrm{L}^{-1}$ of $L$ plantarum into incubating water reduced microbial loads, but did not improve water quality parameters (dissolved oxygen and $\mathrm{pH}$ ) and hatchability of C. gariepinus eggs.
\end{abstract}

\section{Introduction}

African catfish Clarias gariepinus is an important aquaculture species in many African and Asian countries due to its ability to withstand handling stress, disease resistance, tolerance to a wide range of environmental conditions with relatively rapid growth and good quality flesh (Hogendoorn, 1992; Olaniyi and Omitogun, 2013; Keremah and Beregha, 2014). However, adequate supply of quality fish seeds for stocking is one of limiting steps to further intensification and commercialization of
C. gariepinus farming (De Graff and Janssen, 1996; Adewumi and Olaleye, 2011). Production efficiencies of C. gariepinus fish seeds in many hatcheries in Africa are low due to high mortalities of larvae (Aiyelari et al., 2007). As in all cultured fishes under hatcheries conditions, high mortality of larvae during early developmental stages is often attributed to proliferations of opportunistic bacteria and fungi within the rearing environment (Little et al., 2002; Brummett, 2007). Thus, the control of opportunistic microorganism in rearing systems is one of the determinant factors for 
survival of fish larvae (Prol, 2010).

During artificial propagation of Clarid catfishes, an increase in number of microorganisms, especially opportunistic bacteria and fungi (mainly Saprolegnia spp.) on dead eggs, egg shells and incubating water are usually observed soon after hatching (Olaniyi and Omitogun, 2014). The common method of tackling this anomaly in small-scale hatcheries is to flush out water in the hatching tank and replace it with fresh water once the incubation is completed, while the dead eggs and eggs shells are siphoned out into separate tanks as fast as possible after hatching (Diyaolu, 2015). This method agitates the newly hatched larvae which are very fragile at this period, and could result in high losses if handled improperly. Other methods of controlling microorganisms in hatcheries have been proposed (Prol, 2010), but are either difficult or expensive to implement especially under small-scale culture conditions. An effective, eco-friendly approach is therefore required to tackle proliferation of harmful microorganisms in fish hatcheries.

Probiotics are live bacteria, yeast and fungi, which once supplied in sufficient quantities, give a beneficial effect on the host health (FAO/WHO 2002). The use of probiotics have been reported as effective means of controlling disease-causing microorganisms instead of antimicrobial compounds, and as supplements for improving growth of several aquaculture species (Irianto and Austin, 2002). Ogunshe and Olabode (2009) evaluated in-vitro antimicrobial activities of some lactic acid bacteria (LAB) against gram-negative indicator bacterial isolates from $C$. gariepinus and reported that Lactobacillus plantarum inhibited some fish borne pathogen and could thus be used instead of antibiotics during fish production. Experiments on some marine fishes also showed that the use of probiotics during fish larval culture could serve as a means of bio-control measure against pathogenic microorganisms and/or improve larval survival and growth (Vine et al., 2004)

The present study examined potentials of $L$ plantarum isolated from maize slurry as bio-control agents during hatchery propagation of African catfish Clarias gariepinus. This experiment was designed to determine whether addition of probiotcs bacteria to rearing water before egg incubation could reduce heterotrophic bacterial and fungi counts in incubating water and improve water quality without having any adverse effect on fish hatching.

\section{Materials and Methods}

\section{Broodstock Procurement and Artificial Propagation}

Four female and two male African catfish Clarias gariepinus brooders of one year old and mean weight of $1.35 \pm 0.08 \mathrm{~kg}$ were purchased from a reputable broodstock farm. The brooders were maintained in the laboratory at $26.4-27.2^{\circ} \mathrm{C}$, dissolved oxygen $5.6-5.9$ $\mathrm{mg} / \mathrm{L}$ and $\mathrm{pH} 6.6$ - 7.1. Each female fish was kept in a separate container, and were all hormonally induced with Ovaprim (Aquatic Sciences Companies, Holland) at the rate of $0.5 \mathrm{~mL}$ of ovaprim per kilogram of fish, while the males were not induced. The injected brooders were kept in plastic containers containing freshwater throughout the latency period of 12 hours at room (26.5 ${ }^{\circ} \mathrm{C}$ ) temperature, after which they were ready for stripping. The male brooders were sacrificed, and the milt collected from each male was used for fertilization of eggs obtained from the female at the ratio of one male to two females. The injection, stripping and fertilization were done as previously described by Olaniyi and Omitogun (2014).

\section{Preparation of Probiotic Bacteria}

The Lactubacillus plantarum strain used in this experiment was isolated previously from fermented maize slurry, and the sequenced nucleotides were accorded accession number LC333558 by the DNA Data Bank of Japan (DDBJ) (Diyaolu et al., 2018). The strain was preserved in de-Mann Rogosa and Sharpe (MRS) agar slant in the refrigerator. Prior to use, the strain was recovered by aseptically inoculating a loopful of the bacterium from preserved agar slant into $10 \mathrm{~mL}$ sterile MRS broth and incubated at $37^{\circ} \mathrm{C}$ for 24 hours. $5 \mathrm{~mL}$ of cultured broth was further inoculated in 200 litres of sterile MRS broth and incubated. The broth was centrifuged at $3000 \mathrm{rpm}$ for 10 minutes and the supernatant poured off. The cells were washed in sterile phosphate buffer saline (PBS pH 7.0) and re-suspended in $100 \mathrm{~mL}$ PBS solution. $1 \mathrm{~mL}$ of properly mixed PBS cell suspension was serially diluted five fold, and $0.1 \mathrm{~mL}$ of the diluent was plated on MRS agar to determine the concentration of the bacteria, which was found to be approximately $2 \times 10^{10}$ colony forming unit (cfu) per $\mathrm{mL}$ of the PBS cell suspension.

Table 1. Concentration of Lactobacillus plantarum LC3335568 added to different experimental bowls during incubation of C. gariepinus

\begin{tabular}{lc}
\hline Experimental group & Concentration of test bacterial/drug inclusion \\
\hline NC & No test bacteria/no drug \\
PC & $1.0 \mathrm{ppt}$ tetracycline \\
LM1 & $2.0 \times 10^{3} \mathrm{cfu} / \mathrm{L}$ of $L$. plantarum \\
LM2 & $2.0 \times 10^{6} \mathrm{cfu} / \mathrm{L}$ of $L$. plantarum \\
LM3 & $2.0 \times 10^{9} \mathrm{cfu} / \mathrm{L}$ of $L$. plantarum \\
\hline
\end{tabular}

$\mathrm{NC}$ - negative control; PC - positive control 


\section{Experimental Conditions}

Incubation of fertilized eggs of $C$. gariepinus was carried out in 6-litre circular plastic bowls under static water condition. Prior to egg incubation, the bacterial cell suspension was added to water in each bowl to obtain varying concentration of probiotic bacteria (these concentrations were chosen to determine the optimum dosage required during hatching) as presented in Table 1. Three replicates bowls was maintained for each treatment, totaling fifteen bowls in all. $3 \mathrm{~g}$ of fertilized eggs were taken, mixed with $10 \mathrm{ml}$ water, allowed to stay for 1 minute, and quickly spread for incubation in each designated bowl at room temperature. There was no water exchange throughout the incubation period. The incubation lasted 30 hours, after which the hatchlings were visually observed with the aid of magnifying glass. The hatchlings were counted to determine percentage hatchability of the fertilized eggs in each bowl. The resulting hatchlings were recorded to be viable if they moved after gentle tapping on the incubating bowls. Water quality parameters -
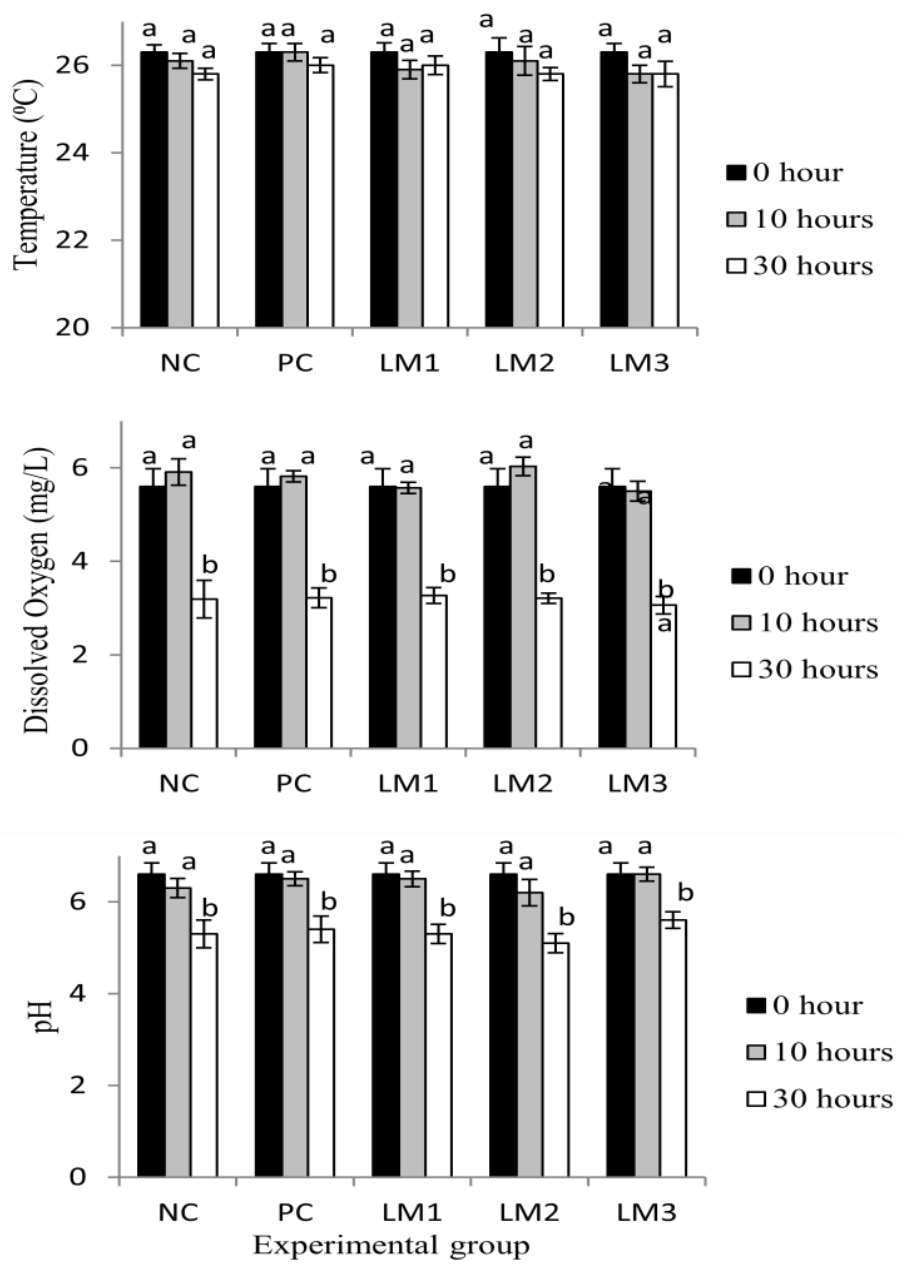

Figure 1. Water quality parameters (temperature, dissolved oxygen and $\mathrm{pH}$ ) of incubating water at 0,10 and 30 hours of incubation of $C$. gariepinus eggs. Groups (bars) having similar letters were not significantly $(p>0.05)$ different

Table 2. Percentage hatchability and observation of hatchlings after incubation of $C$. gariepinus eggs in different concentrations of L. plantarum LC3335568

\begin{tabular}{lcc}
\hline Experimental groups & Hatchability (\%) & Observation on hatchings \\
\hline NC & $69.31 \pm 3.34$ & Viable hatchlings \\
PC & $70.24 \pm 1.95$ & Less viable hatchlings \\
LM1 & $68.55 \pm 5.21$ & Viable hatchlings \\
LM2 & $68.47 \pm 3.05$ & Viable hatchlings \\
LM3 & $\mathrm{NH}$ & - \\
\hline
\end{tabular}

Values from triplicate trials were recorded as mean \pm standard deviation. Means with the same superscript on the same column indicated no significant difference $(\mathrm{p}<0.05)$ from each other. $\mathrm{NH}-$ not hatched 
temperature, dissolved oxygen, and $\mathrm{pH}$ - from each incubation bowl were measured before ( 0 hour), during (10 hours) and after (30 hours) incubation, using digital Hanna Multiparameter (MS 30352 model, Germany).

\section{Microbiological Analyses of the Incubating Water}

The microbial analyses of inflow and incubating water from the experimental groups were carried out using pour plating techniques. Different microbial culturing media, such as nutrient agar (total viable count), Mac Conkey agar (Enterobacteriaceae count), MRS agar (presumptive lactobacillus count) and potato dextrose agar (fungi count), were employed. I $\mathrm{mL}$ of water sample from each incubating bowl was serially diluted to $10^{-4}$. $0.1 \mathrm{~mL}$ aliquot of each sample was plated in sterile triplicate plates. Thereafter, $15 \mathrm{~mL}$ of appropriate sterile agar were poured into each plate, and the plates were allowed to set and incubated at 30 ${ }^{0} \mathrm{C}$. The plates for total viable counts and
Enterobacteriaceae counts were incubated under aerobic condition for 24 hours; those for presumptive lactobacillus counts were incubated under anaerobic condition for 2 days, while those for fungi counts were incubated aerobically for 3 days. After the culture period, the bacteria and fungi in the plates were enumerated and recorded following the methods of Olutiola et al. (1991).

\section{Statistical Analysis}

The data from each experimental group were recorded as mean \pm standard deviation. Analysis of variance (ANOVA) was used to compare means among experimental groups while Duncan Multiple Range test was employed to separate means where significant differences existed. Microbial counts were logtransformed before they were analysed while the analysed values were reconverted to numbers. Bar charts were employed to present analysed results where appropriate.

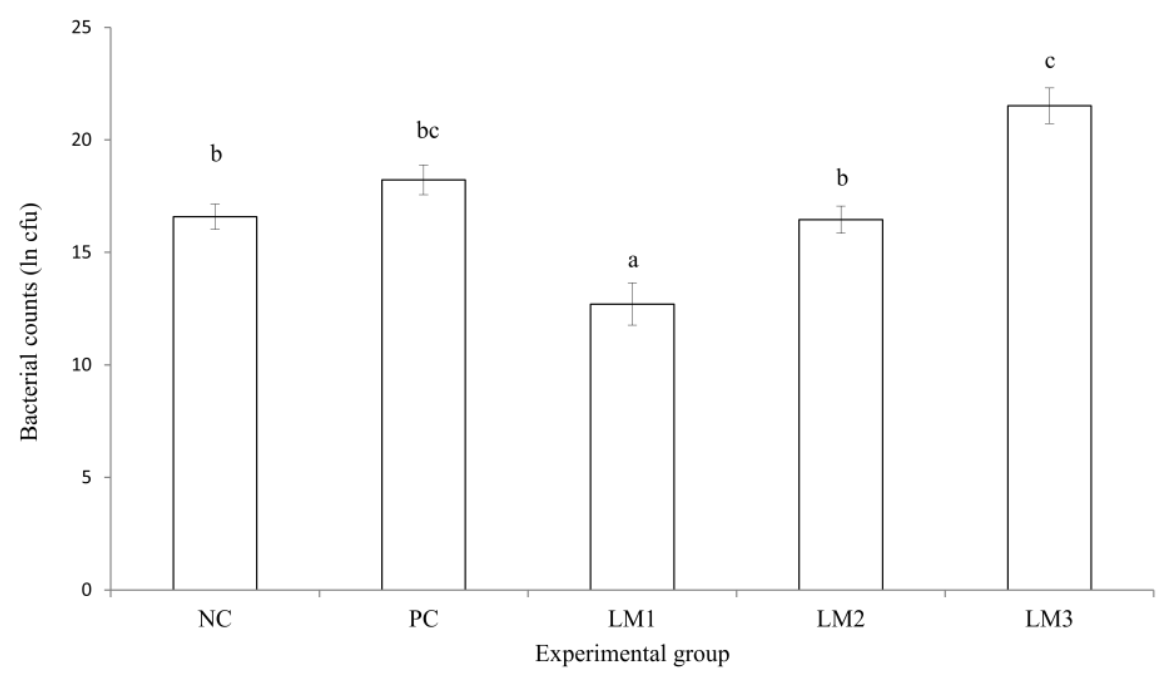

Figure 2. Total bacterial counts recovered from incubating water of $C$. gariepinus eggs at 30 hours of incubation. Error bars indicated standard deviation of triplicate trial. Bars with different superscripts indicated significant differences $(p<0.05)$

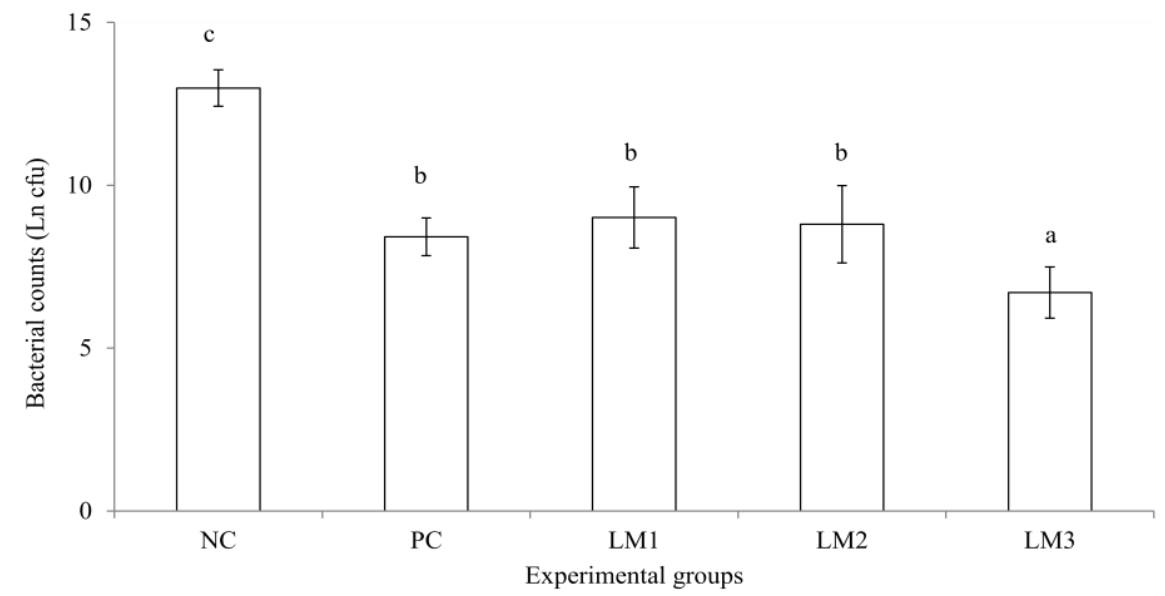

Figure 3. Counts of Enterobacteriacea recovered from incubating water of $C$. gariepinus eggs at 30 hours of incubation. Error bars indicated standard deviation of triplicate trial. Bars with different superscripts indicated significant differences $(p<0.05)$ 


\section{Results}

\section{Water Quality Changes During Egg Incubation.}

The water quality parameter of inflow water was recorded at the onset of the experiment (i.e. 0 hour of incubation). There was no significant change ( $p>0.05)$ in water quality parameters between inflow (at the start of the experiment) and experimental groups at 10 hours of incubation (Figure 1). Except for temperature, egg incubation had remarkable effects on water quality parameters of incubating water as significant reductions $(p<0.05)$ were observed in the values of dissolved oxygen and $\mathrm{pH}$ of water at 30 hours of incubation when compared with those at 10 hour of incubation in all experimental groups. However, these effects were statistical insignificant ( $p>0.05)$ among different experimental groups in parameters tested at 30 hours of incubation.

\section{Microbial Analyses of Incubating Water at $\mathbf{3 0}$ Hours of Incubation}

Total bacterial count in inflow water was below detection $(<30 \mathrm{cfu} / \mathrm{mL})$ level. However, significant changes were observed in the number of microorganism recovered from incubating water in all experimental groups at 30 hour of egg incubation. When compared among experimental groups (Figure 2), total bacterial counts were significantly $(p<0.05)$ highest in LM3 and least in LM1. LM3 groups recorded significantly least counts of Enterobacteriaceae, while significantly lower counts were observed in LMI, LM2 and PC groups than in control (NC) groups (Figure 3 ). In terms of fungi counts (Figure 4), NC and PC groups had significantly highest occurrence of fungi counts. Significantly lowest fungi counts were recorded in LM2 treatment group which received the concentrations of test bacteria of $10^{6} \mathrm{cfu}$
$\mathrm{L}^{-1}$. There was no significant difference $(\mathrm{p}>0.05)$ in fungi counts between LM2 and LM3 groups. Presumptive lactobacilli (LAB) were not detected in both control (NC) and tetracycline (PC) groups, and were significantly reduced $(p<0.05)$ in LM1 and LM2 groups than in group LM3, when compared to the test bacterial concentration initially added to each bowl. It was observed that the values recovered in all treatments bowls containing test bacteria at 30 hours of incubation were more than $50 \%$ of the originally added test bacteria (Figure 5).

\section{Hatchability of C. gariepinus Eggs}

The result of the hatchability of $C$. gariepinus eggs incubated in water inoculated with different concentrations of L. plantarum LC3335568 are presented in Table 2. The fertilized eggs did not hatch in treatments groups with test bacteria concentrations of $2 \times 10^{9} \mathrm{cfu} \mathrm{L}^{-1}(\mathrm{LM} 3)$, whereas the viable hatchlings were seen in NC, PC, LM1 and LM2 treatment groups. Hatchability was observed to be similar (ranging from $68.47 \%$ to $70.24 \%)$ among groups that hatched. However, it was observed that hatchlings in PC group were less viable even when the incubating bowls were vigorously agitated.

\section{Discussion}

The intensive rearing of fish larvae is highly susceptible to bacterial and fungi infections (Little et al., 2002). Thus, controlling opportunistic microorganisms and maintaining adequate water quality parameters in the hatcheries are very essential for the survival of fish larvae. Probiotics have arisen as a new strategy to address the proliferation of microbes, avoiding the use of antibiotics and disinfectants (Pro, 2010). This study demonstrated the effectiveness of $L$. plantarum as probiotics in C. gariepinus hatcheries where egg

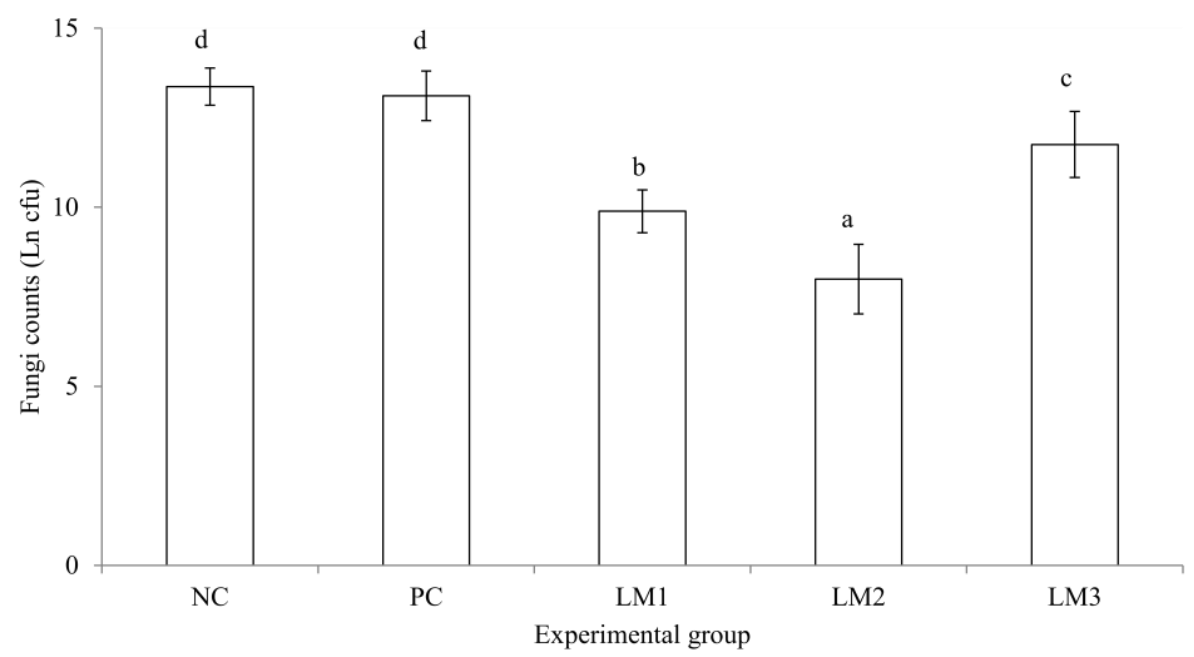

Figure 4. Fungi counts recovered from incubating water of $C$. gariepinus eggs at 30 hours of incubation. Error bar indicated standard deviation of triplicate trial. Bars with different superscripts indicated significant differences $(p<0.05)$ 
incubation is usually carried out under static water condition.

Addition of $2 \times 10^{6} \mathrm{cfu} \mathrm{L}^{-1}$ L. plantarum LC3335568 into incubating water in the present study was observed to be effective in reducing the numbers of Enterobacteriaceae and fungi in water during egg incubation. This observation might be due to the antibacterial and antifungal activities of $L$. plantarum against heterotrophic bacteria and fungi developing in the incubation tank. According to Song et al (2014), L. plantarum produces antimicrobial compound known as plantaricin, which has a bactericidal mode of action against other microorganisms by dissipating the proton motive force or by creating the pores in the cell membrane that permits the efflux of relatively large molecules. Some researchers have also reported that $L$. plantarum can produce antifungal substances, such as benzoic acid, methylhydantoin, mevalonolactone and other metabolites that inhibit the growth of fungi and other species of bacteria (Niku-Paavola et al., 1999; Sjogren et al., 2003; Prema et al., 2008). However, the mechanisms by which these antimicrobial substances dissociates in water and exert inhibitory actions against other microorganisms inhabiting the same aquatic medium need to be established.

Viability is an important property of any probiotics which enable them to function effectively (Vine et al., 2004). In the present study, high presumptive lactobacilli counts were recovered in all probioticinoculated experimental groups at 30 hours of incubation, suggesting that test bacteria can remain viable in the incubating water throughout the incubation period. However, this period is too short to draw any conclusion on their ecological adaptability to the aquatic environment. Further studies are therefore required to validate the persistence of the introduced bacteria in the incubation water.
Different concentrations of L. plantarum employed in this study did not affect incubating water parameters differently, although dissolved oxygen and $\mathrm{pH}$ of water in all treatment and control groups dropped drastically during egg incubation. Similar changes in water quality parameters are generally reported during early developmental stages of Clarid catfishes (Olaniyi and Omitogun, 2014). The change in dissolved oxygen and $\mathrm{pH}$ in all treatments observed in this study might be occasioned by increase in chemical and biological oxygen demands (COD and BOD) in the incubating bowls, due to the rapid decomposition of dead eggs and egg shells toward the end of incubation process (Prol, 2010; Olaniyi and Omitogun, 2014). This pinpoints the necessity of water exchange once the egg incubation is complete to avoid hatchlings mortality resulting from poor water quality.

It was generally presumed that beneficial bacteria could be added into incubating water at high concentration in order to increase the chance of their attachment to the newly hatched larvae (Prol, 2010). In the present study, treatment groups with test bacterial concentrations of $2 \times 10^{9} \mathrm{cfu} \mathrm{L}^{-1}$ recorded no hatching of C. gariepinus eggs. The reason for this result is unclear, although earlier reports of Maeda (1994) suggested that level of bacteria greater than $10^{6} \mathrm{cfu}$ per litre of water during egg incubation might not favour hatchability of fish eggs. The implication of this result is that $C$. gariepinus eggs may not require any bacteria medium to hatch and hatching process may not be negatively affected by beneficial bacterial concentration of or below $10^{6} \mathrm{cfu} \mathrm{L}^{-1}$.

It was observed that the efficacy of tetracycline solution (PC) in reducing the numbers of Enterobacteriaceae was similar to that of the probiotic groups. However, hatchlings from PC groups were observed to be less viable when compared with other

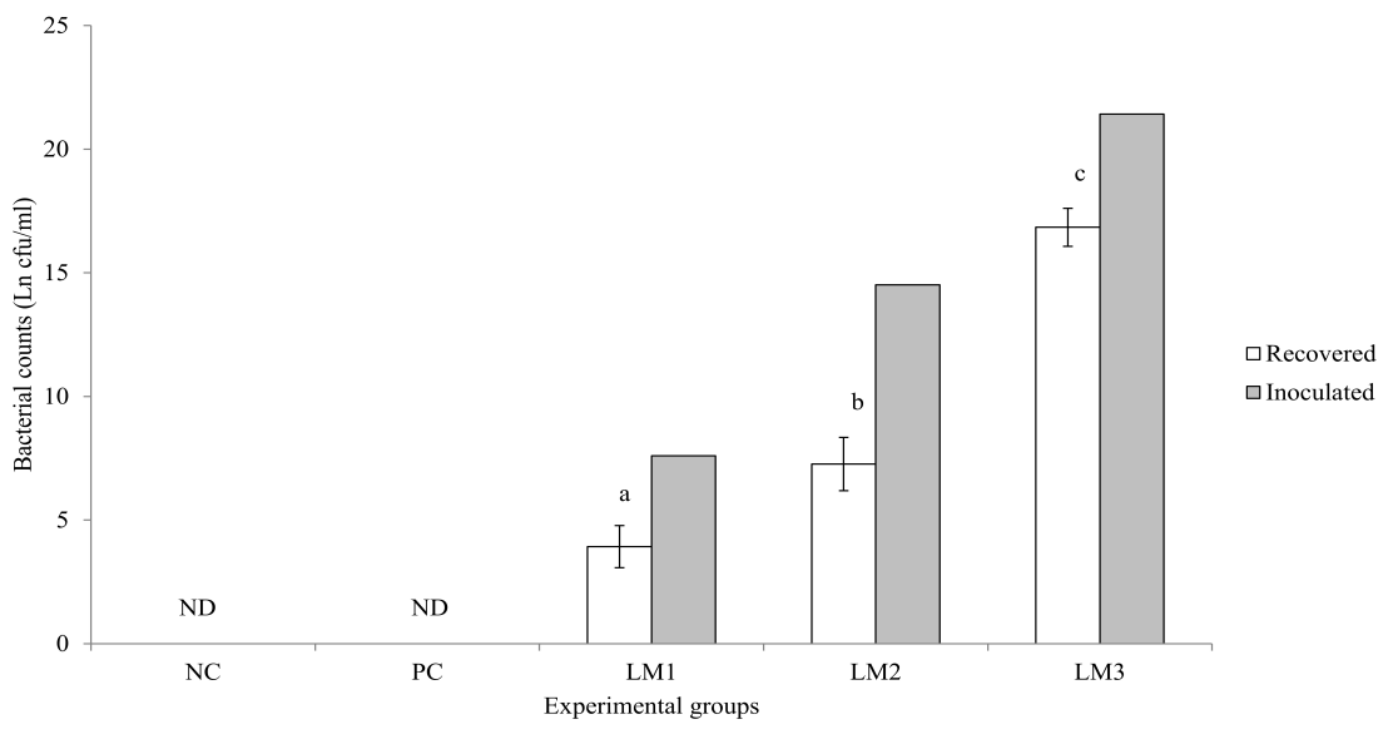

Figure 5. Counts of presumptive lactobacilli inoculated and recovered from incubating water of $C$ gariepinus eggs at 30 hours of incubation. Error bars indicated standard deviation of triplicate trial. Bars with different superscripts indicated significant differences $(p<0.05)$. ND - not detected. 
probiotic-treatment groups. According to Skjermo and Vadstein (1993), the use of chemotherapeutics during egg incubation may be deleterious to resulting hatchlings by causing loss of beneficial, slow-growing bacteria populations ( $K$ strategists), and promoting the rapid colonization by fast-growing opportunistic bacteria ( $r$ strategists) which are potentially harmful to fish larvae. This result supports the views of Vine et al. (2004) on the use of probiotics as a valid alternative to chemotherapeutic agents for controlling microbial proliferations and improving larval survival and growth during fish larval culture.

\section{Conclusion}

The present research indicated that $L$ plantarum LC3335568 can reduce microbial loads if employed as bio-control agent during egg incubation of $C$. gariepinus. The optimum concentration was observed to be $2 \times 10^{6}$ $\mathrm{cfu} \mathrm{L}^{-1}$. However, incubating water must be discharged immediately and replaced with fresh water once hatching processes are complete to avoid loss of resulting hatchlings due to poor water quality. Further research is warranted to monitor larval growth and assess whether introduction of beneficial bacteria during egg incubation enhance colonization of larval gut by these introduced bacteria.

\section{Ethical Statement}

The experiment was performed in accordance with relevant guidelines and approval by the Ethical Committee on Animal Experiment of the Federal University of Technology Akure, Nigeria (reference number: FUTA/SAAT/2018/002).

\section{Funding Information}

The author received no funding for this research

\section{Author Contribution}

Conceptualization: DOD; Investigation: DOD; Methodology: DOD, Project Administration: DOD; Supervision: DOD; Writing -original draft: DOD, Writing review and editing: $D O D$

\section{Conflict of Interest}

The author declares that he has no known competing financial or non-financial, professional, or personal conflicts that could have appeared to influence the work reported in this paper.

\section{Acknowledgements}

The author appreciates the technologists (Mr. Ojuola, Mr. Morankinyo and Mr Fred) at the Aquaculture Teaching and Research Farm of the Federal
University of Technology, Akure, Nigeria, for their technical assistance.

\section{References}

Adewumi A. A. and Olaleye V. F. (2011) Catfish culture in Nigeria: Progress, prospects and problems. African Journal of Agricultural Research 6(6): 1281 - 1285

Aiyelari T. A., Adebayo, I. A. and Osiyemi, A. S. (2007) Reproductive fitness of stressed female broodstock of Clarias gariepinus (Burchell, 1809). Journal of Cell and Animal Biology 1 (5): 78-81

Brummett R. E. (2007) Freshwater fish seed resources and supply. African Regional Synthesis. Pp. $41-58$. In: M. Bondad-Reantaso (ed) Assessment of freshwater fish seed resources for sustainable aquaculture. FAO Fisheries Technical Paper No.501, FAO Rome

Corsetti A., Gobbetti M. and Smacchi E. (1996) Antimicrobial activity of Sourdough Lactic acid bacteria: Isolation of bacteriocin-like inhibitory substance from Lactobacillus sanfrancisco C57. Food Microbiology 13: $447-456$

De Graaf, G. J. and Janssen, H. (1996) Artificial Reproduction and Pond Rearing of the African Catfish, $C$. gariepinus in Sub-Saharan Africa. FAO Fisheries Technical Paper 362: 1 $-73$

Diyaolu, D. O. (2015) Aerobic bacterial flora and survival of African catfish Clarias gariepinus during early life stages in the hatchery. International Journal of Fisheries and Aquatic Studies 3(1): 380-384

Diyaolu, D. O., Fasakin, E. A., Ekundayo, F. O. and Adebayo O. T. (2018) Phenotypic and molecular characterization of different isolates of Lactobacillus plantarum from four Nigerian fermented foods for use as probiotics in aquaculture. Brazilian Journal of Biological Sciences 5 (10): 329-337

FAO/WHO (2006) Probiotics in food: Health and nutritional properties and guidelines for evaluation. Food and Nutrition Paper 85. Food and Agriculture Organization (FAO) and World Health Organization (WHO). Rome, Italy.

Hogendorn, A. H. (1992) Controlled propagation of African Catfish Clarias gareipinus. Aquaculture 21:233-241

Irianto, A. and Austin, B. (2002) Probiotics in aquaculture. Journal of Fish Diseases 2002, 25: 633-642.

Keremah, R. I. and Beregha, O. (2014) Effect of varying dietary protein levels on growth and nutrient utilization of African catfish Clarias gariepinus fingerlings. Journal of Experimental Biology and Agricultural Sciences 2(1): 13 18.

Lategan, M. J., Torpy, F. R. and Gibson, L. F (2004) Control of Saprolegniosis in the eel Anguilla australis Richardson, by Aeromonas media strain A199. Aquaculture 240: 1927.

Little, D. C., Tua, P. A. and Bermann, B. (2002) Health management issues in freshwater fish hatcheries, nurseries and fry distribution with emphasis on experiences in Viet Nam and Bangladesh. Pp $141-146$. In: I. B. Arthur, M. J. Phillips, R. P. Sabasinghe, M. B. Reantasso and I. H. MacRae (eds) Primary aquatic health care in rural, small scale aquaculture development. FAO Fisheries Technical Paper No. 406. FAO, Rome

Maeda, M. (1994) Bio-control of the larval rearing biotope in aquaculture. Bulletin of National Research Institute of Aquaculture 1: 71-74. 
Niku-Paavola, M. L., Laitila, A., Mattila-Sandholm, T. and Haikara, A. (1999) New types of antimicrobial compounds produced by Lactobacillus plantarum. Journal of Applied Microbiology 86: 29-35

Ogunshe, A. O. and Olabode, P. O. (2009) Antimicrobial potentials of indigenous Lactobacillus strains on gramnegative indicator bacterial species from Clarias gariepinu (Burchell): microbial inhibition of fish-borne pathogens. African Journal of Microbiology Research 3(2): $870-876$.

Olaniyi, W. A. and Omitogun, O. G. (2013) Stages in the early and larval development of the African catfish Clarias gariepinus (Teleostei, Clariidae). Zygote 22:314-330

Olaniyi, W. A. and Omitogun, O. G. (2014) Embryonic and larval developmental stages of African giant catfish Heterobranchus bidorsalis (Geoffroy Saint Hilaire, 1809) (Teleostei, Clariidae). SpringerPlus 3: 677-691.

Olutiola, P. O., Famurewa, O. and Sonntag, H. G. (1991) An introduction to general microbiology: a practical approach. Germany, Hygiene-Institute der University Heidelberg.

Prema, P., Smila, D., Palavesam, A. and Immanuel, G. (2008) Production and characterization of an antifungal compound (3-phenyllactic acid) produced by Lactobacillus plantarum strain. Food Bioprocess Technology 3: 379-386.

Prol, M, J. (2010) Immobilization of Phaeobacter 27-4 in biofilters as a strategy for the control of Vibrionaceae infections in marine fish larval rearing. Ph.D Thesis at Instituto De Acuicultura, Spain, $195 \mathrm{p}$

Sjogren, J., Magnusson, J., Broberg, A., Schnurer, J. and Kenne, L. (2003) Antifungal 3-hydroxy fatty acids from Lactobacillus plantarum MiLAB 14. Applied Environment Microbiology 69: 7554-7557.

Skjermo J and Vadstein O (1993) Characterization of the bacterial flora of mass cultivated Brachionus plicatilis. Hydrobiologia 255/256: 185-191.

Song, D. F., Zhu, M. Y., and Gu, Q. (2014). Purification and characterization of plantaricin ZJ5, a new bacteriocin produced by Lactobacillus plantarum ZJ5. PLOS One 9:e105549.

Vine N. G., Leukes W. D., Kaiser H., Daya S., Baxter J and Hecht T (2004) Competition for attachment of aquaculture candidate probiotic and pathogenic bacteria on fish intestinal mucus. Journal of Fish Diseases 27: 319-326. 